\title{
The Relationship between Employee Attributes and Customer Satisfaction: A Case of South African Call Centre Industry
}

\author{
Muswera Nyasha
}

University of Fort hare, Department of Business Management, P. Bag, X1314, Alice 5700, South Africa. Email: nmuswera77@gmail.com.

Jordaan Ben D

University of Fort Hare Department of Business Management, P. Bag, x1314, Alice, 5700, South Africa Email: bdjordaan@ufh.ac.za

Matikiti Rosemary

University of Fort Hare, Department of Business Management, P. Bag X 1314, Alice, 5700, South Africa Email: matikiti@gmail.com

Doi:10.5901/mjss.2014.v5n23p396

\section{Abstract}

Business survival, success and profitability are in the final instance customer or client dependent, therefore, every enterprise aims at maximising customer need-satisfaction in the endeavour to maximise profitability. With this in mind, the primary objective of this study is to establish the relationship between customer satisfaction and employee attributes as experienced by call centre customers. In addition, the study investigated how customers prioritise service quality dimensions as well as the mediating role played by customer satisfaction on the linkage between service quality and customer loyalty. To accomplish this, firstly, the direct relationship between the individual independent variables was tested and secondly, the indirect relationship between service quality and customer loyalty via customer satisfaction was tested. A combination of simple and multiple regression analysis was applied to test the hypothesised relationships. The results show that employee attributes and call centre key service factors significantly impact customer satisfaction and that call centre customers prioritise service quality dimensions differently. The mediating role of customer satisfaction on the linkage between service quality and customer loyalty was partially significant.

Keywords: Customer satisfaction, employee attributes, call centre, customer loyalty

\section{Introduction}

The call centre industry has grown considerably over the last decade, mainly due to technological advances and the decline in costs of communications and data transmission, making it easier for the firms in the various industries to provide improved customer service (Benner, Lewis \& Omar, 2007:9). A call centre is a physical or virtual operation within an organisation in which a managed group of people spend most of their time rendering business services by telephone, usually in a computer-automated environment (Robbins \& Coutler 2005:345). A call centre allows a firm to build, maintain and manage customer relationships by solving problems and resolving complaints quickly, having information, answering questions and being available. Call centres are forming the heart of successful customer relationship strategies; they provide firms with valuable information about the performance of their services. Thus, allowing firms to understand how customers feel about service quality. Most business organisations see call centres as a potentially effective way of keeping customers happy and satisfied and gaining a competitive advantage (Dean 2002:414).

Customer satisfaction on the other hand is dependent upon the service provided by a business organisation and how the service is delivered. Thus service firms should focus its attention on both its customers and employees as satisfied employees are likely to be friendly, upbeat and responsive, all of which the customer appreciates (Robbins \& Coulter, 2005:346). Simon, Gomez, McLaughlin and Wittink (2008:27) argue that in retail scenery, employee attitudes directly influence customer satisfaction with the service. Therefore, a firm's service marketing strategy should not only be for external marketing but also for internal marketing, to motivate employees; in addition, also interactive marketing, to 
create service delivery skills among service providers (Kotler \& Armstrong, 1999:267).

Marketing literature provides theoretical insights into the customer satisfaction formation process in the context of consumer products and services. Little research has addressed customer satisfaction in developing countries. Few studies have been conducted in the South African call centre industry, most of these only focused on call centre job satisfaction, human resource practices and performance (Benner, et al., 2007, Gordi, 2006 \& Werner, 2006). The linkage between employee attributes and customer satisfaction has not been empirically proven, nor has research been conducted to seek a deeper understanding of the exact nature of the relationship between customer satisfaction with services and the service provider attributes.

Consequently, this study focused on the relationship between customer satisfaction and employee attributes in South African call centres more specifically, call centre customers in the Eastern Cape Province of South Africa.

\subsection{Problem statement}

Customer satisfaction with the firm's product or service is a key indicator of a firm's success and long-term sustainability and competitiveness (Henning-Thurau \& Klee, 1997:737). Sviokla and Shapiro (1993) concur and argue that the focus on keeping customers satisfied should be as natural to a business enterprise as is breathing to a human being. Customer satisfaction through improved service quality from service employees possessing the correct attributes, amongst others: anticipating customer requests, offering explanations or justifications, educating the customer, providing emotional support and offering personalised information; has become increasingly important in service-rendering enterprises employing call centres. The nature of the service encounter between the call centre and the customer is predominantly conducted through technology. Hence, firms in developing countries may struggle to manage their call centres in delivering best services to their customers. Call centres are becoming progressively integral parts of most business enterprises in offering improved and efficient customer service, which are key service factors of customer satisfaction (Henning-Thurau \& Klee, 1997:738).

Existing literature has explored mainly, customer satisfaction in business- to- business exchanges and customer satisfaction in buyer-to-supplier mainly in technologically advanced countries such as the UK and the US (Homburg, Kromer, Cannon \& Kiedaisch, 2002:1). Thus, little work has been conducted in developing countries such as South Africa to establish the relationship between employee attributes and customer satisfaction in South African call centre industry. To close the gap this paper has addressed the issue.

\subsection{Objectives of the paper}

In a bid to address the gap found in literature this paper seeks to achieve the following

- To establish the relationship between customer satisfaction and employee attributes as experienced by call centre customers in the Eastern Cape Province of South Africa.

- To explore and identify service quality dimensions and their prioritisation in the perception of the Eastern Cape call centre customers,

- To establish the nature of the relationship between call centre key service factors and customer satisfaction, and

- To establish if customer satisfaction experienced from call centres increase customer commitment and loyalty to the firm.

- To achieve these objectives the study proposed a conceptual framework from which the hypotheses of this paper were formulated. The variables used in the study were compiled after consulting a number of previous studies (Henning-Thurau \& Klee, 1997; Homburg et al, 2002; Lovelock \& Gummersson, 2004; Laroche et al, 2004)

Figure 1: Proposed conceptual framework

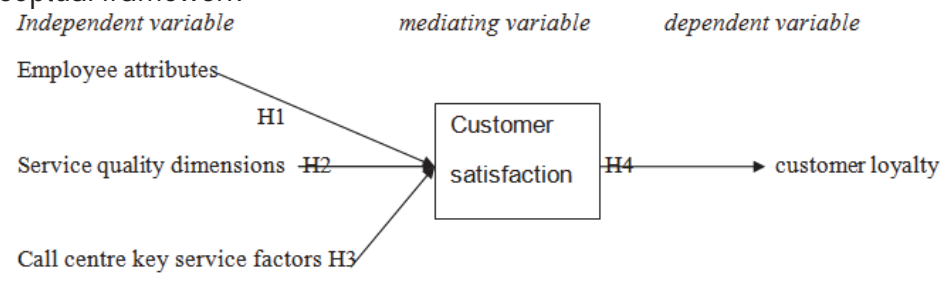




\subsection{Hypotheses}

H10:No significantly positive relationship exists between customer satisfaction and employee attributes in call centres as experienced by consumers in the Eastern Cape Province of South Africa

$\mathrm{H} 20$ : Service quality dimensions do not equally impact the level of customer satisfaction in a call centre;

$\mathrm{H} 30$ : Call centre key service factors negatively influence customer satisfaction in call centres;

$\mathrm{H} 4_{0}$ :Customer satisfaction does not mediate the relationship between service quality level delivered by call centre representatives and customer loyalty;

\section{Literature Review}

It is believed that the first new generation call centres were developed in the USA in the 1980s and a few years later adopted in Australia and the UK (Brown \& Maxwell, 2002:309). The oldest centres are found in the telecommunications and retail sectors, reflecting the early development of advanced engineering systems in telecommunications and catalogue sales in the retail sector. However, Holman, Batt and Holtgrewe (2007:12) conclude that almost all call centres are now using advanced information technologies to handle customer inquiries. This implies that call centres in different countries are converging on a set standard. According to Holman, et al. (2007:6), after conducting a survey of almost 2,500 call centres in 17 countries, South Africa included, found that the nature of the call centre industry is very similar in terms of markets, service offerings, organisational structure and workforce characteristics.

According to Benner, et al. (2007:10) the first call centres in South Africa emerged in the 1970s, but it was only in the late 1990s that the combination of improved computer technology and reduced telecommunications costs contributed to a rapid growth of the industry. Benner, et al. (2007) conducted a survey on SA call centres between 2003 and 2004. The major findings of this survey reflected that most of call centres in South Africa are located in the country's major economic hubs and serve the regional and international markets. The industry has grown considerably since the turn of the century with a growth rate of $8 \%$ per annum. It employs approximately 54000 call centre agents and contributes approximately a lot to the gross domestic product of the nation (Benner et al, 2007). Thus, if properly managed it has a capability of improving the economy of the country.

\subsection{The service marketing}

The development of service-oriented concepts and models started in the 1970s, though it is suspected that there were some earlier services marketing publications (Grönroos, 2006:317). Grönroos (2006) acknowledges Lynn Shostack's 1977 article as the pioneering work that promoted service marketing as an interesting and acceptable field of research.

Service marketing is founded upon the fundamental concepts of marketing specifically the philosophy or customer orientation (Gilmore, 2003:6). According to Gilmore (2003:3) the service sector account for most of the new job growth in both developed and still developing nations. Services' marketing has been successful because it differentiated itself in the marketplace with a conceptual paradigm shift that services are different from goods (Lovelock \& Gummesson, 2004:21). The authors comment that the drift from goods to services is reinforced by the emergence of the Internet during the late 1990s. This shift is confirmed by the fast growth of the call centre business in the marketplace. However, Grönroos (1995:252) argues that service firms are fuelled by relationships and concludes that the nature of service businesses such as banks, insurance firms, transportation firms and retailers, is relationship oriented. Grönroos (1995:252 ), thus, defines services marketing as a way of inviting customers to use the service processes by making promises about value that can be expected to be captured from the service (Grönroos, 2006:324). The author urges call centres are to implement these processes in a way that allows customers to perceive that value is created in their service experience, that is, promise keeping through value fulfilment.

\subsection{The service quality}

Recent literature holds that service quality remains a potent force in marketing but mainly as a fundamental component of customer value (Woodall, 2001:597). Miciak and Desmarais (2001:340) allege that service quality management is now the concern of all business enterprises and call centres are playing an increasingly important role in the customer service experience. Brink and Berndt (2004:70) and Gronroos (2000:62) define service quality as perceived by customers, and thus, refer to the firm's ability to accurately determine customer expectations and to deliver the service at a quality level that will at least meet those customer expectations. However, the service quality concept has many inherent difficulties in 
implementing and evaluating in a service firm (Hoffman, Bateson, Wood and Kenyon, 2009:402). This difficulty occurs primarily owing to the unique characteristics of services (inseparability, intangibility, heterogeneity and perishability). Unlike goods, where customers evaluate the finished product only, with services customers evaluate the whole process of the service and its outcome. Grönroos' 1984 deconstruction model of service quality led to his identification of three principal components in service quality, namely, technical quality, functional quality and corporate image (Woodall, 2001:595). This model concluded that a firm's image is determined by both conventional and emergent marketing techniques, but also significantly depends upon both the customer expectations and perceptions of the firm's technical and functional quality.

According to Kasper, Helsdingen and Gabboth (2006:183) and Grönroos (2000:79), there are a variety of service quality models that have been developed and measured over the years which include the Nordic or Grönroos Model, the SERVQUAL Model, the Disconfirmation Model, the Six Sigma Model and the Gummesson 4Q Model of service quality. Attention was paid to the SERVQUAL model only for this study in an attempt to better understand call centre service quality concept. The model was chosen because it is less complicated and more applicable to the call centre survey. Thus, the SERVQUAL was chosen to investigate the research problem as it was more appropriate and easier to apply for this research.

\subsection{The SERVQUAL model}

The most frequently cited model of customer service is the SERVQUAL model (Burns, Graefe \& Absher, 2003:364). It was developed by Parasuraman, Zeithmal and Berry $(1985,1988)$ to address quality issues in service delivery systems. The authors developed a method of examining consumer's expectation levels and perceived performance for a series of relevant attributes. The SERVQUAL model is based on five dimensions that customers use in assessing service quality. Hoffman, et al. (2009:410) describe the SERVQUAL model as a diagnostic tool that uncovers a firm's broad weaknesses and strengths in the area of service quality. The model consists of two sections, namely, a 22-item section that records customer expectations of excellent firms in the specific service industry and another 22 -item section that measures customer perceptions of a particular firm in that service industry. The results from the two sections are then compared to obtain the "gap scores" for each of the five dimensions. The larger the gap, the further the customer perceptions are from expectations, the lower the service quality evaluation and the reverse is true for a smaller gap. On one hand, the customer expectations are measured on a 7-point scale with the anchor labels of "not at all essential" and "absolutely essential". On the other hand, the customer perceptions are measured on another 7-point scale with anchor labels of "strongly agree" and "strongly disagree". Thus, the 44-item scale SERVQUAL instrument measures both customer expectations and perceptions considering the tangibles, reliability, responsiveness, assurance and empathy (Baran, Galka, Strunk, 2008:398). Thus, these dimensions were adopted in the construction of the instrument for this study.

\subsection{Customer satisfaction}

Marketing literature has paid considerable attention to customer satisfaction in recent years. This growing interest can be credited to the belief that customer satisfaction affects a number of desirable outcomes such as, customer loyalty, wordof-mouth promotion and purchases in a firm. As a result, customer satisfaction has received increased attention as a corporate goal in addition to traditional financial measures of success (Dolen, Ruyter and Lemmink, 2002:437). Hoffman and Bateson (2006:300) agree and state that customer satisfaction is the most studied concept in marketing. The authors hold that much research in the customer satisfaction area began in the 1970s, when consumerism arose as a direct result of a decline in service-quality experienced by many consumers. In line with the rise in consumerism since the 1970s marketing researchers conclude that the importance of customer satisfaction cannot be overstated, as customers are the sole reason why firms are in existence (Hoffman \& Bateson, 2006:303). Consequently, customer satisfaction has become an important cornerstone of customer-oriented business practices for firms that operate in diverse industries and global markets (Laroche, Ueltschy, Abe, Cleveland \& Yannopoulos, 2004:58). Studies revealed that satisfaction ratings are viewed as means to strategic ends such as repurchase behaviour and customer retention.

In a bid to explain the concept of customer satisfaction a number of models where developed namely; the expectations disconfirmation model, perceived performance model, norms model, multiple process model, attribution model affective model and the equity model (Hom, 2003:105). Amongst these models the expectations disconfirmation model has received applause from a number of researchers (Oliver 1997, Mickinney, Yoon \& Zahedi, 2002; Syriam, 2010) because it is easy to understand and clearly explains the concept of customer satisfaction. The model holds that consumers have pre-consumption expectations that they compare to post-consumption experiences of a service to form 
an attitude of satisfaction or dissatisfaction toward the service. The model assumes that these customer expectations originate from beliefs about the level of performance that a market offering will provide. It is widely believed that customer satisfaction is positively linked to customer loyalty.

\subsection{Customer Loyalty}

Customers have become harder to please. They are now smarter, more price sensitive, more demanding, less forgiving and faced with a wider array of choices than ever before (Kotler \& Keller, 2006:154). Hence, the "leaky bucket" approach to marketing practiced in the past, when markets were growing, no longer works (Kotler \& Armstrong, 1999:6). They purport that firms are now faced with new market realities such as changing demographics, slow growth economies, technological advances, more sophisticated competition and globalisation, all of which increase pressure on marketers to build stronger bonds with their existing customers so as to survive in the marketplace. According to Kotler and Keller (2006:157), it is five times more expensive to attract a new customer than retain an already existing one, thus, good marketing strategies that are not just promotional hypes and promises but that constantly deliver real value to their customers are needed to build customer loyalty. Brink and Berndt (2004:32) assert that customer loyalty is more than having customers make repeat purchases and being content with their experiences and products or services they purchase. Customer loyalty implies that customers are committed to purchasing products or services from a specific enterprise and will resist the activities of rivalry firms attempting to attract their support. Hence, the role of call centres in a business of building meaningful relationships between a firm and its customers becomes increasingly crucial.

\section{Methodology}

The population for this study consisted of inhabitants the Eastern Cape province of South Africa who has engaged with a call centre in the past twelve months preceding the survey. Only those inhabitants who are employed and have a regular income, literate and at least have twenty-one years were chosen for this study. The qualifying study units (respondents) were approached irrespective of the call centre service provider they have engaged with. Being employed or having regular income and being literate, increased the likelihood that a respondent had experienced a call centre service engagement, thus reducing the time spent screening respondents. Being at least twenty-one years of age, eliminated the need for obtaining guardian or parental consent, thereby adhering to the specified ethical requirements during research. Lastly, the requirement that the engagement with a call centre should have been in the past twelve months reduced the need for relying on very long-term memory, thus reducing the level of inaccuracy due to memory loss.

The measuring instrument for this study was developed using the five dimensions adopted from the SERVQUAL Model namely tangibles, reliability, responsiveness, assurance and empathy (Baran, et al. 2008:398). Thus, these dimensions were adopted in the construction of the measuring instrument for this study. To collect primary data, the researchers used a combination of shopping-mall intercepts and self-administered questionnaires. During the mallintercepts, the interviewer posed questions to the respondents or shoppers face-to-face, mainly to gather quantitative data. The researchers used hand-delivery method to distribute the questionnaire to the call centre customers at the malls of towns in the Eastern Cape Province of South Africa. The questionnaires were given to the screened call centre customers to complete on the spot and any misconceptions were immediately clarified by the field workers. Thus, a 5 point linket and 7 point linkert type questions adapted from a 22 item service quality measuring instrument (SERVQUAL) by Zeithaml, Parasuraman and Berry (1990:20) were used. However the study did not include the physical aspect (tangibles) since it was deemed inappropriate for this study so it used only 18 items. The variables for employee attributes used for this study where anticipating customer request, offering explanations, educating customers and providing emotional support and the call centre key factors included in the study where; first call resolution, duration of waiting time, product knowledge of CCR and follow up services. To test the reliability of the instrument the internal consistency approach, specifically, the coefficient alpha also referred to as the Cronbach's alpha was used. SPSS Version 19.0 was used to analyse data especially for inferential statistics.

\section{Results and Discussion}

All 200 questionnaires handed out were completed; however, only 165 questionnaires were retained as useable and valid for analysis. The 35 questionnaires were rejected for various reasons including not meeting the required criteria specified in the previous research methodology chapter. In comparing the expected sample size and the actual sample size, it can be reported that a significantly high response rate of $82.5 \%$ was obtained for this survey. 


\subsection{Reliability}

To ascertain the reliability of the instrument this Cronbach's Alpha reliability tests and factor analysis, namely, exploratory factor analysis was performed on the research constructs. The empirical results indicate that the entire variable used in the study where reliable. Empirical results on Table 1 shows an average of 0.925 Cronbach's alpha coefficient on all variables measured for customer expectations. The Cronbach alpha test was also performed to measure the reliability of customer perception and a coefficient of 0.954 was obtained meaning that all the variables were reliable as well.

Table 1: Reliability results

Table 1: Cronchbach Alpha of Constructs

\begin{tabular}{|c|c|}
\hline Variable & Cronchbach Alpha Coefficients \\
\hline Customer expectation & 0.925 \\
\hline Customer perception & 0.954 \\
\hline
\end{tabular}

Thus the cut-off point for Cronbach alpha set for this study is 0.6 and the results on Table 1 shows that the Cronbach alpha exceeds the cut-off for the study meaning that all the variables used to measure customer expectation were reliable.

\subsection{Results of hypotheses testing}

All the hypotheses formulated for this study were tested using simple regression analysis and the results are shown on Table 2.

Table 2: Results of the Simple Regression Analysis

\begin{tabular}{|c|c|c|c|}
\hline Hypothesis & Correlation between variables & p-value & Correlation coefficient \\
\hline H1 & employee attributes............customer satisfaction & 0.000 & $0.726^{*}$ \\
\hline H2 & service quality dimensions....customer satisfaction & 0.644 & $0.605^{\star}$ \\
\hline H3 & call centre key factors.........customer satisfaction & 0.000 & $0.252^{*}$ \\
\hline
\end{tabular}

* tested at $99 \%$ confidence interval

The empirical results of the simple regression analysis on Table 2 show that the correlation coefficient between the averages of the call centre employee attributes and the overall customer satisfaction is positive and moderate (0.726) and highly significant $(p=0.000)$. A correlation coefficient of $r=0.726$ means that a unit change in employee attributes will result in an increase of $72.6 \%$ in customer satisfaction. Thus, the null hypothesis $\left(\mathrm{H1}_{0}\right)$ for the first hypothesis is rejected, and we conclude that there is a moderately, significant positive relationship between customer satisfaction and employee attributes in call centres as experienced by consumers in the Eastern Cape Province.

The empirical results of the simple regression analysis on Table 2 again show that the correlation coefficient between the means of the service quality dimensions and the overall customer satisfaction is positive and moderate (0.605), however, the result is not significant since $p=0.644$. Thus, the results confirm that there is no statistical significance to support the hypothesis that service quality dimensions equally impact the level of customer satisfaction in a call centre as experienced by customers in the Eastern Cape Province of South Africa. Hence, null hypothesis (H20) for the second hypothesis is not rejected, and it can be concluded that service quality dimensions do not equally impact the level of customer satisfaction in a call centre.

This result are consistent with the views put forward by Quinlivan,Boyask and Carswell (2008: 135) in their tertiary education study, as well as the hotel study by Sriyam (2010:34), the authors concluded that some service quality dimensions have more impact than others on the overall customer satisfaction.

Lastly The results of the simple regression analysis on Table 2 showed that the correlation coefficient between the averages of call centre key factors and the overall customer satisfaction is positive and weak (0.252) and highly significant since $p=0.000$. The results confirm that, though the relationship between the two variables is weak, there is however, statistical significance to support the hypothesis that call centre key service factors enhance call centre client's overall satisfaction. Since, a unit increase in any of the call centre key service factors will result in a $25.2 \%$ increase in customer satisfaction. Thus, the null hypothesis $\left(\mathrm{H}_{3}\right)$ for the third hypothesis is rejected, and it can be concluded 


\section{that call centre key service factors positively influences customer satisfaction in call centres.}

The fourth hypothesis formulated for this study was to ascertain the relationship between service quality level delivered by call centre representatives and customer loyalty. Due to the mediating variable the fourth hypothesis was tested using a four step regression process. Empirical results from the multiple regression analysis are presented in Table 3.

Table 3: Results of the Multiple Regression Analysis

\begin{tabular}{|c|c|c|c|c|c|}
\hline Step & Variables & Beta & Constant & Standard error & $\mathrm{p}$-value \\
\hline 1 & service quality.............. customer loyalty & 1.046 & -0.172 & 0.065 & 0.010 \\
\hline 2 & service quality ........customer satisfaction & 0.958 & -0.078 & 0.073 & 0.000 \\
\hline 3 & customer satisfaction......customer loyalty & 1.055 & 0.027 & 0.100 & 0.000 \\
\hline 4 & service quality + customer satisfaction... & $\begin{array}{c}1.070- \\
0.025 \\
\end{array}$ & -0.174 & $\begin{array}{l}0.066 \\
0.012\end{array}$ & 0.000 \\
\hline
\end{tabular}

The equation used to test this hypothesis is as follows;

Let: $X$ be equal to Service Quality (SQ)

$M$ be equal to Customer Satisfaction (CSAT)

$Y$ be equal to Customer Loyalty (CUSLO)

\section{Step 1}

A simple regression analysis with $X$ predicting $Y$ was conducted and the results of the analysis were used to formulate the equation relating service quality and customer loyalty. The equation:

\section{$Y=1.046 X-0.172$}

The first step shows that the initial variable, service quality, is positively correlated with the outcome, customer loyalty (beta $=1.046$ ). This result confirms that there is an effect that may be mediated.

\section{Step 2}

Again, a simple regression analysis with $\mathrm{X}$ predicting $\mathrm{M}$ was conducted and an equation relating service quality and customer satisfaction was formulated.

$$
X=0.958 X-0.078
$$

The analysis indicates that the initial variable, service quality, is also positively correlated with the mediator, customer satisfaction, with beta equal to 0.958 . The essence of this step was to check if the mediator, customer satisfaction has any relationship with the independent variable, service quality.

\section{Step 3}

A simple regression analysis with $\mathrm{M}$ predicting $\mathrm{Y}$ was also, conducted and also, the equation relating customer satisfaction and customer loyalty was formulated.

\section{$Y=1.055 X+0.027$}

The analysis indicates that the mediating variable, customer satisfaction affects the outcome variable, customer loyalty (beta $=1.055$ ), however, it is not sufficient just to correlate the mediator with the outcome, because the mediating variable $(M)$ and the dependent $(Y)$ may be correlated because they are both caused by the independent variable $(X)$. Thus, the independent variable must be controlled in establish the effect of the mediating variable on the outcome variable.

\section{Step 4}

In order to establish the effect of the mediating variable, customer satisfaction, a multiple regression analysis with $X$ and $M$ predicting $Y$ was conducted.

$$
X+M------Y \quad Y=1.070 X-0.025 \mathrm{M}-0.174
$$

The results on Table 3 show that all three variables are positively correlated. However, to establish that customer satisfaction completely mediates the $X-Y$ relationship (that is, relationship between service quality and customer loyalty), the effect of $X$ on $Y$ controlling $M$ should be zero. Whereas, in this case as shown by the fourth equation, the effect of $X$ on $Y$ controlling $M$ is -0.025 , indicating that mediation is incomplete. However, Baron and Kenny (1986) maintain that, if the first three steps are met but the step 4 not, then partial mediation is indicated. Thus, it can be concluded that customer satisfaction partially mediates the service quality customer loyalty relationship for call centre customers in the Eastern Cape province of South Africa.

Thus, the null hypothesis $\left(\mathrm{H}_{0}\right)$ for the fourth hypothesis is rejected, and it may be concluded that customer satisfaction does partially mediate the relationship between service quality level delivered by call 


\section{centre representatives and customer loyalty.}

This research result was supported by other studies claiming that the acquisition of a new customer can costs five times more than retaining existing customers and also, that a two percent increase in customer retention has the same effect on profits as cutting costs by 10 percent (Ramakrishnan, 2006:3). This evidence supports the notion that an improvement in service quality delivery enhances customer satisfaction that in turn improves a firm's level of customer loyalty.

\section{Research Contributions}

\subsection{Theoretical}

As stated earlier, a limited number of studies have been conducted in developing countries addressing the relationship between customer satisfaction and employee attributes in the call centre industry. Of the few studies done, the majority only focused on call centre job satisfaction, human resource practices and performance (Benner, et al., 2007, Gordi, 2006 and Werner, 2006). However, this study empirically researched the relationship between employee attributes and overall customer satisfaction in the call centre industry. The results of the research study confirm that a number of variables namely, employee attributes, service quality dimensions and call centre key service factors, show positive relationships with overall customer satisfaction and also, that customer satisfaction partially mediates the relationship between service quality and customer loyalty in call centres as experienced by call centre customers

\subsection{Practical contribution}

In the call centre industry the challenge of providing high quality productive customer experiences, becomes easier when managers know what customers' needs are, and correctly assess the importance that customers attach to individual elements that make up the total call centre experience. Given how critical customer satisfaction data is in developing successful call centre strategies, the research results have important implications for South African call centre managers. Considering the multi-dimensional nature of factors affecting call centre customer satisfaction, call centre managers should ensure that these service factors work together in a systematic and synergistic manner to secure the delivery of quality experiences to their valued call centre customers. The current level of overall dissatisfaction with the call centre services, reflected by the gap between customer expectations and customer perceptions as measured by the SERVQUAL questionnaire, appears to be largely determined by the level of customer perceptions of employee attributes, service quality dimensions, and other call centre service factors.

Considerable responsibility is vested in call centre management to be informed about the current levels of satisfaction with their businesses and to display a sincere commitment to improve service delivery to new heights. This responsibility is particularly critical given the fact that these components significantly increase the likelihood of recommendations and advocacy, in other words, generating favourable word-of-mouth service promotion. In today's highly competitive market, most firms' survival depends greatly on its ability to provide superior service delivery experience that enhances customer satisfaction.

Therefore, it is recommended that in striving to offer superior customer call centre services, call centre managers should identify each encounter in the service chain that they wish to focus on. They then have to single out those that are of operational or strategic significance, focusing in on the few encounters that really make a difference to guest experience and to sustain the firm's bottom line. The management should ensure that each separate encounter is executed in an efficient manner because every service encounter, in itself, is either a success or a failure that in turn affects the success or failure of the whole service experience. It is further recommended that call centre managers undertake periodic call centre customer satisfaction assessments, as satisfaction cannot be improved without measuring it. By assessing their customers' overall satisfaction levels, areas for improvement in the service delivery chain could be identified.

\section{Limitations and Directions for Future Research}

Firstly, the researcher did the measurement of perceived service quality in terms of customer perceptions and expectations at the same time. Respondents attempted to compare their perceptions of call centre service quality with their expectations. Studies undertaken in future should separate the two measurements.

Secondly, respondent bias might have occurred due to the demographic composition of the sample that was not 
fully representative of the whole population. This can be ascribed to the fact that the convenient sampling method was used to collect the data for this survey.

Thirdly, it could also be argued that the study results might have been different, had the survey been conducted over a longer period in place of the cross sectional survey that was used.

\section{Conclusion}

The major conclusions drawn from the research results are that various service factors affect call centre customer satisfaction. These include employee attributes (anticipating customer requests, offering explanations or justifications, educating and informing the customer, providing emotional support, and offering individualised information), service quality dimensions (reliability, responsiveness, empathy and assurance) and call centre service factors (the first call resolution, duration of waiting time, product knowledge of the call centre representative and follow up services). All these variables indicate positive relationships with the overall customer satisfaction.

The results also reveal that call centre customers rank the various service quality dimensions differently in terms of importance. The empirical findings reflect that customer satisfaction partially mediates the relationship between service quality and customer loyalty. Thus, call centre management need to focus their resources in maximising areas that yield an optimal customer satisfaction level and stakeholder value.

\section{References}

Baran, R.J., Galka, R.J. \& Strunk, D.P. (2008) Principles of Customer Relationship Management. Ohio: Thomson South-Western.

Benner, C., Lewis, C. \& Omar, R. (2007). The South African Call Centre Industry: A Study of Strategy, Human Resource Practices and Performance. (In: LEAH, S. 2005. Increasing Customer Satisfaction through Employee Satisfaction in a Call Centre Environment. Published Master of Science Thesis. Menomonie: University of Wisconsin Stout).

Brink, A. \& Berndt, A. (2004). Customer Relationship Management and Customer Service. Lansdowne: Juta \& Co. Ltd.

Brown, G. \& Maxwell, G. (2002). Customer Service in UK Call Centres: Organisational Perspectives and Employee Perceptions. Journal of Retailing and Consumer Services, 9(2002): 309-316, January

Burns, R.C., Graefe, A.R. \& Absher, J.D. (2003). Alternate Measurement Approaches to Recreational Customer Satisfaction: Satisfaction Only Versus Gap Scores. Journal of Leisure Sciences 25(4): 363- 382, June.

Dean, A. (2002). Service Quality in Call Centres: Implications for Customer Loyalty. (In: Gordi, M.R. 2006. Job Satisfaction of Call Centre Representatives. Published Master of Arts Thesis. Cape Town: University of Western Cape).

Dean, A. (2004). Service Quality in Call Centres: Implications for Customer Loyalty. Journal of Managing Service Quality, 12(6): 414423, June.

Dolen, W., Ruyter, K. \& Lemmink, J. (2002). An Empirical Assessment of the Influence of Customer Emotions and Contact Employees Performance on Encounter and Relationship Satisfaction. Journal of Business Research, 57(1): 437- 444, February.

Gilmore, A. (2003). Services Marketing and Management. London: SAGE Publications.

Gordi, M.R. (2006). Job Satisfaction of Call Centre Representatives. Published Master of Arts Thesis. Cape Town: University of Western Cape.

Grönroos, C. (1995). Relationship Marketing: The Strategy Continuum. Journal of the Academy of Marketing Science, 23(4): 252-254, September.

Grönroos, C. (2000). Service Management and Marketing: A Customer Relationship Management Approach. England: John Wiley \& Sons.

Grönroos, C. (2006). Adopting a Service Logic for Marketing. Journal of Marketing Theory, 6(3): 317-333, February.

Henning-Thurau, T. \& Klee, A. (1997). The Impact of Customer Satisfaction and Relationship quality on Customer Retention - A Critical reassessment and Model Development. Journal of Customer Satisfaction, 14(8): 737-764, December.

Hoffman, K.D. \& Bateson, J.E.G. (2006). Services Marketing: Concepts, Strategies and Cases. Ohio: Thomson South-Western.

Hoffman, K.D., Bateson, J.E.G., Wood, E.H. \& Kenyon, A.J. (2009). Services Marketing: Concepts, Strategies and Cases. London: South-Western CENGAGE Learning EMEA.

Holman, D., Batt, R. \& Holtgrewe, U. (2007). The Global Call Center Report: International Perspectives on Management and Employment [On-line]. Available: http:www.globalcallcenter.org [Accessed: 12 April. 2010].

Hom, W. (2003). An Overview of Customer Satisfaction Models [On-line]. Available: http://viewer.zoho.com/api/urlview.do? url=http://www.staging.rpgroup.org/documents/publications/ConfProceedings-WorkshopPapers/38th-Conf-May-2000/03-HomCustomer-Satisfaction-Models.pdf [Accessed: 25 March. 2011].

Homburg, C., Kromer, H., Cannon, J.P. \& Kiedaisch, I. (2002). Customer Satisfaction in Transnational Buyer-Supplier Relationships. Journal of International Marketing, 10(4): 1-29, December.

Kasper, H., Helsdingen, P. \& Gabboth, M. (2006). Service Marketing: A Strategic Perspective. $2^{\text {nd }}$ Edition. London: John Wiley \& Sons.

Kotler, P. \& Armstrong, G. (1999). Principles of Marketing. 8thEdition. Upper Saddle River: Prentice-Hall International.

Kotler, P. \& Keller, K.L. (2006). Marketing Management. 12th Edition. Upper Saddle River: Pearson Prentice Hall. 
Laroche, M., Ueltschy, L.C., Abe, S., Cleveland, M. \& Yannopoulos, P.P. (2004). Service Quality Perceptions and Customer Satisfaction: Evaluating the Role of Culture. Journal of International Marketing, 12(3): 58- 85, March.

Lovelock, C. \& Gummesson, E. (2004). Whither Services Marketing? In Search of a New Paradigm and Fresh Perspectives. Journal of Service Research, 7(1): 20-41, August.

Mckinney, V., Yoon, K. \& Zahedi, F.M. (2002). The Measurement of Web-Customer Satisfaction: An Expectation and Disconfirmation Approach. Journal of Information System Research, 13 (3): 296- 315, September.

Miciak, A. \& Desmarais, M. (2001). Benchmarking Service Quality Performance at Business-to-Business and Business-to-Consumer Centers. Journal of Business Industrial Marketing, 16(5): 340- 353, November

Oliver, R.L. (1997). Satisfaction: A Behavioural Perspective on the Consumer. (In: Fellesson, M., Friman, M., Haataja, S., Leite, M. E., Lovén, L., Røer, A. \& Vihervuo, M. 2009. The Relationship Between Objective Quality and Customer Satisfaction [On-Line]. Available: [Accessed: 25 March. 2011].

Parasuraman, A., Zeithaml, V.A. \& Berry, L.L. (1985). A Conceptual Model of Service Quality and Its Implications for Future Research. Journal of Marketing, 49 (1): 41-50, October.

Parasuraman, A., Zeithaml, V.A. \& Berry, L.L. (1988). SERVQUAL: A Multiple-Item Scale for Measuring Consumer Perceptions of Service Quality. Journal of Retailing, 63(1): 12-37, June.

Quinlivan,K, Boyask, R \& Carswell, S. (2008). Dynamics of power and participation in Schools/Universities partnership. New Zealand Journal of Education Studies, 43(1) 130-141.

Ramakrishnan. K. (2006). Customer Retention: The Key To Business Performance [On-line]. Available: http://www.estrategicmarketing. com/smNov-Dec2/art11.html [Accessed: 11 December. 2011].

Robbins, S.P. \& Coulter, M. (2005). Management. $8^{\text {th }}$ Edition. Upper Saddle River: Prentice-Hall, Inc.

Simon, D.H., Gomez, M.I., Mclaughlin, E.W. \& Wittink, D.R. (2008). Employee Attitudes, Customer Satisfaction, and Sales Performance: Assessing the Linkages in US Grocery Stores. Journal of Managerial and Decision Economics, 30(2): 27-41, October.

Sriyam, A. (2010). Customer Satisfaction Towards Service Quality of Front Office Staff at the Hotel. Published Master of Arts Project in Business English for International Communication. Bangkok: Graduate School, Srinakharinwirot University.

Sviokla, J.J. \& Shapiro, B.P. (1993). Keeping Customers. (In: Samuel, G. 2005. The Relationship Between Leadership and Internal Customer Satisfaction Within a Motor Manufacturing Company in Gauteng. Published Master of Business Administration thesis. Grahamstown: Rhodes University).

Werner, A. (2006). Work Dyfunctions and Their Consequences As Experienced By Call Centre Agents: An Exploratory Study. Published Master of Arts Thesis. Cape Town: University Of Stellenbosch.

Woodall, T. (2001). Six Sigma and Service Quality: Christian Grönroos Revisited. Journal of Marketing Management, 17(5): 595- 607, February.

Zeithaml, V.A., Parasuraman, A. \& Berry, L.L. (1990). Delivering Quality Service: Balancing Customer Perceptions and Expectations. New York: Free Press. 